\title{
The Effect of Ionizing Radiation on Microorganism in some spices
}

\author{
khalid K. AL.Bayatti \\ College of Pharmacy - AL-Mustansiriya University - Baghdad-Iraq
}

\begin{abstract}
Summery
The present study was undertaken to evaluate the use of ionizing radiation in decontaminating the total microbial burden of Capsicum peppers (Capsium annuum), Caraway (Carum carvi), and Clove (Dianthus caryphyllus). The spices were irradiated in polyethylene bags with 5KGy and 10KGy of gamma radiation from Co-60 irradiator. Total number of bacteria and molds survived per gram of spices after irradiation were calculated. Results showed that $5 \mathrm{KGy}$ gamma radiation reduced the total number of bacteria by $95-98 \%$ and the number of molds and yeast by $62.8-98.2 \%$, while $10 \mathrm{KGy}$ reduced the total number of bacteria by $95.5-99.9 \%$ and the number of the molds and yeast by 67 $99.7 \%$. These percentages are accepted within the maximum permissible microbial counts for human consumption except mold and yeast counts in caraway which its number was still more than the maximum permissible count for human consumption, and the doses used in these experiments have no significant changes on the sensory quality of the spices.
\end{abstract}

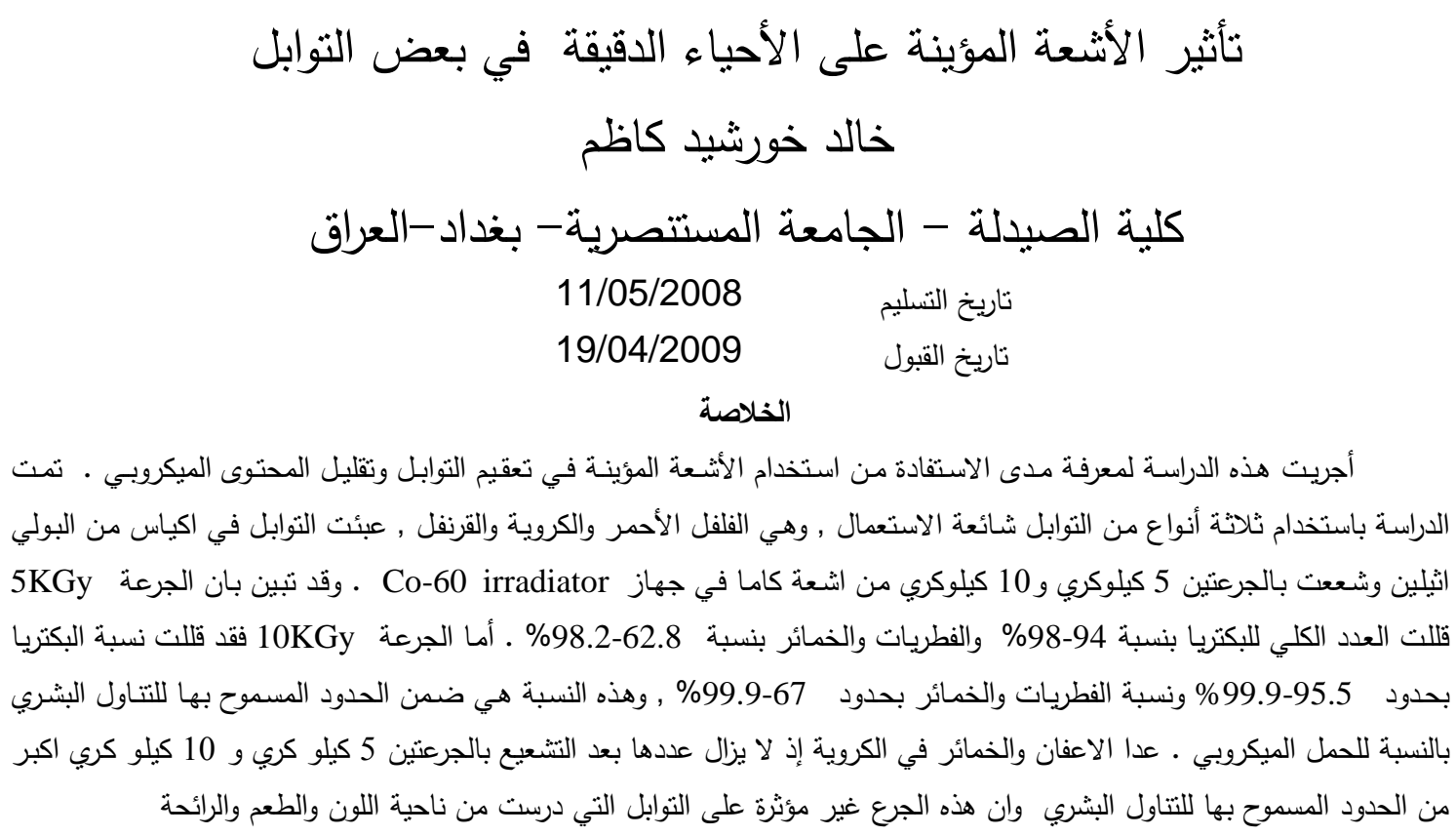

\section{Introduction}

Spices are used in virtually all categories of the food industry, meat, fish, vegetable products and bakery products. There is an increasing demand around the world for spices in connection with increasing amount of processed food, which must be flavored (1).

With regard to spices, both producers and food industries face the problem of the high microbial count of spices, especially contamination by molds (2) and heat-resistant bacterial spores (3).In general, black peppers, caraway, coriander, capsicum peppers, ginger, marjoram and turmeric are the most highly contaminated spices. The total viable count may reach the 80-100 million per one gram(4) , the majority of the microbial flora of spices consists of aerobic and anaerobic spore-forming bacteria ,including genera of Bacillus, Salmonella and Clostridium (5). Powers et.al (6) tested 110 samples of various spices for incidence and level of Bacillus cereus, the organism was found in $53 \%$ of the spices and counts ranged from 50 to 8500 per gram. Of the isolates, $89 \%$ were enterotoxigenic. The frequent occurrence of Bacillus cereus in spices is significant with respect to food safety and sanitation . 
Spices play a major etiological part in mold contamination of meat products $(2,3)$. Spices examined for mold counts have revealed that Penicillium species, Aspergillus glaucus , Aspergillus niger, and Aspergillus flavus are frequently found to varying extent $(7,8)$.

Relative high incidence of toxigenic molds has been found in spices $(8,9,10)$ and several authors have detected aflatoxins in a range of spices $(11,12)$ although the levels of aflatoxin recorded are generally low.

Chemical treatment of spices with ethylene oxide (EO) or propylene oxide (PO) is used commercially in several countries to reduce the viable cell counts, but what is more serious disadvantage, such as toxic chemical residue, inducing mutagenic effects, propylene oxide is causing carcinogenic effects in animal tests $(13,14)$.

Heat sterilization, Microwave treatment and UV radiation had also been applied in an attempt to control microorganisms in selected spices, but all of them were considered to be unsuitable to bring about decontamination (15).

Electron bombardment technique, X-rays, and gamma rays have been employed for the sterilization of spices, however because of the limited penetration of the electron been, more penetrating radiation such as gamma rays, can be applied. It was established to achieve nearly total sterilization (i.e. a reduction of total viable counts to less than 10 microorganisms per gram) a reduction dose of 8 to 20 KGy is required, depending on the initial level of contamination (5).

The purpose of the present study is to reduce the viable number of bacteria and molds in some selected spices, capsicum pepper, caraway and clove to lower allowable number for human consumption using as low dose of gamma radiation as possible without altering or destroying the spice sensor quality as color, odor and flavor and chemical structure.

\section{Materials and Methods}

Spices: All spices were purchased from local markets.

Irradiation of spices: Samples of 10 gram of spice (capsicum peppers, caraways and cloves) were placed in polyethylene containers and irradiated with total doses of 5KGy and $10 \mathrm{KGy}$ gamma rays from Co-60 irradiator.

Total viable counts of Bacteria and Molds:

One gram of irradiated spices were suspended in $100 \mathrm{ml}$. of sterilized saline solution $(0.9 \% \mathrm{Nacl})$, agitated vigorously and serial decimal dilutions were made. Then $3 \mathrm{ml}$ of the same dilution were added to 3 plates (one ml. on each plate to give about 100-300 colonies per plate) containing $25 \mathrm{ml}$ per plate of sterilized nutrient agar, and incubated at $37^{\circ} \mathrm{c}$ for $48 \mathrm{hrs}$.

For total mold counts, the same dilution procedure was followed, and $3 \mathrm{ml}$ of the specified dilutions were plated on 3 potato-dextrose agar plates and incubated at $25^{\circ} \mathrm{c}$ for 5-7 days. At the end of the incubation period, total number of bacterial or mold colonies were counted on each plate and the mean number of 3 plates of the same dilution was calculated per gram of the irradiated spices .

For control samples, the same pervious procedure was followed using unirradiated spices.

\section{Results and Discussion}

Table 1 represents the effect of 5KGy and 10KGy of gamma radiation on capsicum pepper. Total number of viable counts of bacteria after 5KGy irradiation was reduced by two log cycle (98\% killing ) and after 10KGy irradiation was reduced by three log cycle (99\% killing ). The number of bacteria remained per gram of capsicum pepper after 10KGy irradiation was within the maximum allowable number for human consumption according to the International Standards (4). 
For molds and yeast, total number of viable counts have also been reduced by one log cycle (94\% killing ) and two log cycle (99\% killing ) after exposure of capsicum pepper to 5KGy and $10 \mathrm{KGy}$ respectively .

Table (2) shows the effects of the same gamma radiation doses (5KGy and $10 \mathrm{KGy}$ ) on the number of viable counts of bacteria and molds on caraway, the number reduced by one log cycle for both doses or the killing rates were $94 \%$ and $95 \%$ for bacteria and $63 \%$ and $67 \%$ for molds and yeast for dose of $5 \mathrm{KGy}$ and $10 \mathrm{KGy}$ respectively. The number of viable counts of molds and yeast after irradiation with $10 \mathrm{KGy}$ was still more than the maximum allowable counts per gram of the caraway, this may due to some technical errors in experimentation or may need more doses of radiation to reduce the number to the allowable counts for human consumption, although the experiment repeated two times but ends with the same results. The mold contamination of spices is highly important because of the microbial flora of the spices, only molds are capable of growth in storage at an ambient temperature and a minimum relative humidity of $72-75 \%$ (17), this may illustrate the reason why the number of viable counts of molds and yeast in the present study on the caraway was still more than the maximum allowable counts after irradiation with 5KGy and $10 \mathrm{KGy}$. Thus the ability of surviving microorganisms in irradiated spices after irradiation for several months was high.

Table (table 3) shows the effects of irradiating cloves with 5KGy and 10KGy gamma radiation. In turn the number of bacteria reduced by one log cycle for both doses (about $95 \%$ and $98 \%$ killing rates respectively). For molds and yeast their number were reduced by one log cycle also (98\% killing rate ) after 5KGy irradiation and three log cycles (99.9\% killing rate ) after $10 \mathrm{KGy}$ irradiation, the remaining number of bacteria and molds per gram of irradiated cloves are within the maximum allowable number for human consumption according to the International Standard (4).

The results obtained in this study are in accordance with the results obtained by (18) and Vajdi and Pereira (15) and the level of the viable counts are generally accepted as maximal counts of the decontaminated spices desired in the spice trade (17).

Irradiation of food at less than 10KGy significantly reduces the number of many spoilage pathogenic bacteria; it is less effective in reducing the number of relatively radiation-resistant spores of certain pathogenic bacteria such as Clostridium botulinum (19).

It is noteworthy that no significant changes were observed in the sensory quality like flavor, odor and color of the capsicum pepper, caraway and cloves respectively, after exposure to 5KGy and 10KGy doses levels, this agree with the finding of $(15,16,18)$ where they found less damage to the color and volatile oil content of various spices decontaminated by gamma irradiation than in those treated with ethylene oxide.

Researcher in India found that chili powder capsicum, common spice, black pepper and turmeric can actually prevent bacteria from being destroyed by irradiation, this finding may have practical medicinal uses. Extracts from these spices potentially can protect other organisms (not only bacteria) from the damaging effects of gamma radiation. These researchers believe that certain spices extracts have the potential to protect healing tissues in people undergoing radiation therapy (20). Two antioxidants in black pepper and turmeric (piperine and curcumin ) were found to help protect the bacterial DNA from damage by irradiation, the researcher evaluate the spices against two microorganisms during the study E.coli and B.megaterium (21).

We recommend that capsicum pepper and cloves ought to be irradiated in a well-sealed containers with doses not to exceed 10KGy gamma radiation, while caraway might need more than 10KGy irradiation to reduce the microbial counts to permissible human consumption levels and have no damaging effects on the sensory quality of the spices, like color, odor and flavor before releasing to the markets for general public consumption. 
Table (1): Effects of 5KGy and 10KGy gamma radiation on total microbial counts of capsicum pepper

\begin{tabular}{|c|c|c|c|c|}
\hline \multirow{2}{*}{$\begin{array}{c}\text { Dose } \\
\text { KGy }\end{array}$} & $\begin{array}{c}|c| \\
\text { Total count } \\
\text { cell/gm }\end{array}$ & \% Killing & Total count & $\begin{array}{c}\% \text { Killing } \\
\text { cell/gm }\end{array}$ \\
\cline { 2 - 5 } 0 & $3.6 \times 10^{8}$ & 0 & $9.5 \times 10^{7}$ & 0 \\
5 & $4.7 \times 10^{6}$ & 98.7 & $5.6 \times 10^{6}$ & 94.2 \\
10 & $3.6 \times 10^{5}$ & 99.9 & $2.0 \times 10^{5}$ & 99.8 \\
\hline
\end{tabular}

Table (2): Effects of 5KGy and 10KGy gamma radiation on total microbial counts of caraway

\begin{tabular}{|c|c|c|c|c|}
\hline \multirow{2}{*}{$\begin{array}{c}\text { Dose } \\
\text { KGy }\end{array}$} & \multicolumn{2}{|c|}{ Bacteria } & \multicolumn{2}{c|}{ Fungi and Yeast } \\
\cline { 2 - 5 } & $\begin{array}{c}\text { Total count } \\
\text { cell/gm }\end{array}$ & \%Killing & $\begin{array}{c}\text { Total count } \\
\text { cell/gm }\end{array}$ & \% Killing \\
\hline 0 & $5.7 \times 10^{4}$ & 0 & $1.4 \times 10^{7}$ & 0 \\
5 & $3.3 \times 10^{3}$ & 94.2 & $5.2 \times 10^{6}$ & 62.8 \\
10 & $2.5 \times 10^{3}$ & 95.5 & $4.5 \times 10^{6}$ & 67 \\
\hline
\end{tabular}


Iraqi Journal of Veterinary Medicine Vol. 33, No. 1, 2009

Table (3): Effects of 5KGy and 10KGy gamma radiation on total microbial counts of clove

\begin{tabular}{|c|c|c|c|c|}
\hline \multirow{2}{*}{$\begin{array}{c}\text { Dose } \\
\text { KGy }\end{array}$} & \multicolumn{2}{|c|}{ Bacteria } & \multicolumn{2}{c|}{ Fungi and Yeast } \\
\cline { 2 - 5 } & $\begin{array}{c}\text { Total count } \\
\text { cell/gm }\end{array}$ & \%Killing & $\begin{array}{c}\text { Total count } \\
\text { cell/gm }\end{array}$ & \% Killing \\
\hline 0 & $8.4 \times 10^{7}$ & 0 & $5.4 \times 10^{8}$ & 0 \\
5 & $4 \times 10^{6}$ & 95.2 & $1 \times 10^{7}$ & 98.2 \\
10 & $1.2 \times 10^{6}$ & 98.5 & $6 \times 10^{5}$ & 99.9 \\
\hline
\end{tabular}


References

1. Clark, W.R.E.1970 Modern trends in the application of spices, food manufacture.45:53.

2. Christensen,C,M., Fanse,H.A., Nelson,G.H., Bates,F.1967, and Mirocha,C.J. Microflora of black and red peppers, Appl. Microbiol., 15:622.

3. Yesair,J. and Williams,M.H.1942, Spice contamination and its control, Food Res. 7:118 .

4. Jazsef,Farkas.1983, Radurization and Radicidation : Spices. In: Preservation of food by Ionizing radiation vol.3 CRC press Inc. Boca Raton, Florida..

5. Tjaberg.T.B., Underdal,B.1972, and Lunde,G.,The effects of ionizing radiation on the microbial content and the volatile constituents of spices, J.Appl.Bacteriol,35:473.

6. Powers, E,M., Latt, T.G., and Brown,T.1976, incidence and levels of Bacillus cereus in processed spices, J.Milk Food Technol., 39(10):668.

7. Flannigan, B. and Hui, S.C.1976, the occurance of aflatoxin-producing strains of Aspergillus flavus in the mould floras of ground spices, J.App. Bacteriol.41:411.

8. Pal, N. and kundu, A.K.1972, Studies on Aspergillus spp. From Indian spices in relation to aflatoxin production, Sci. Cult. 30:252.

9. Shank, R.C., Wogan, G.N., and Gibson, J.F.1972, Dietary aflatoxin and human cancer.1. Toxigenic mould in foodstaffs of South-East Asia, Food Cosmet. Toxicol., 10(1):51.

10. Christenson, C.M. 1972, Pure spices - how pure? Am. Soc. Microbiol. ( ASM ) News.38(4):165

11. Zuzuki.J.J., Daninus, B., and Kilbuck,J.H.1973, A modified method for aflatoxin determination in spices, J.Food Sci. 38: 949.

12. Scott, P.M. and Kennedy, B.P.C.1975, The analysis of spices and herbs for aflatoxins, Can. Inst. Food Technol.J., 8:124.

13. Embree,J.W., Iyon,J.P., and Hine,C.H.1977, The mutagenic potential of Ethylene oxide using the dominant lethal assay in rats, Toxicol. Appl. Pharmacol. 40:261.

14. Kucerova, M. and Zhurkov, V.S.1977, Population cytogenic study of mutagenic effects of epichlorohydrin, Mutat. Res. 46:227.

15. Vajdi,M., and Pereira,N.N.1973., Comparative effects of ethylene oxide, gamma irradiation and microwave treatment on selected spices, J. Food Sci. 38(5):893.

16. Radiation of food preservation 2003, Indian National Magazine, The HINDU, .30(17):16-29.

17. Inal,T., Keskin,S., Tolgay,Z., and Zezcam,I.1975 Sterilization of spice by means of gamma rays, Fleischwirtschaft, 55:675.

18. Bechman,S. and Gieszczynska,J.1975, Studies on some microbiological and chemical aspects of irradiated spices, In: Aspects of the introduction of Food Irradiation in Developing Countries, IAEA, Vienna, vol. 33,.

19. Kim,M, Morehouse, 1998 Food Irradiation: The treatment of foods with ionizing radiation ,4(4):9-35.

20. Arun, Sharma.2000 Common spices protect bacteria during irradiation, J.Agricult. Food chem.., April(17).

21. Dennis, Loney.2007 Spice and Bacteria, American Chemical Society, May(8),. 